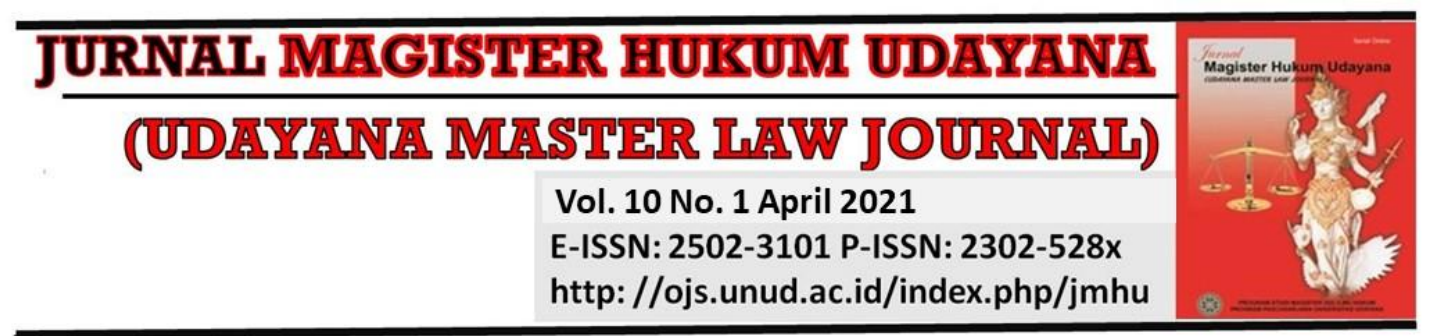

\title{
Pengaturan Perlindungan Hukum Terhadap Smell Sebagai Merek dalam Perspektif Hak Kekayaan Intelektual
}

\author{
Ni Made Cindhi Duaty Githasmara ${ }^{1}$, I Made Sarjana ${ }^{2}$
}

1PT. Eklanku Indonesia Cemerlang, E-mail: githasmara@gmail.com

${ }^{2}$ Fakultas Hukum Universitas Udayana, E-mail made_sarjana@unud.ac.id

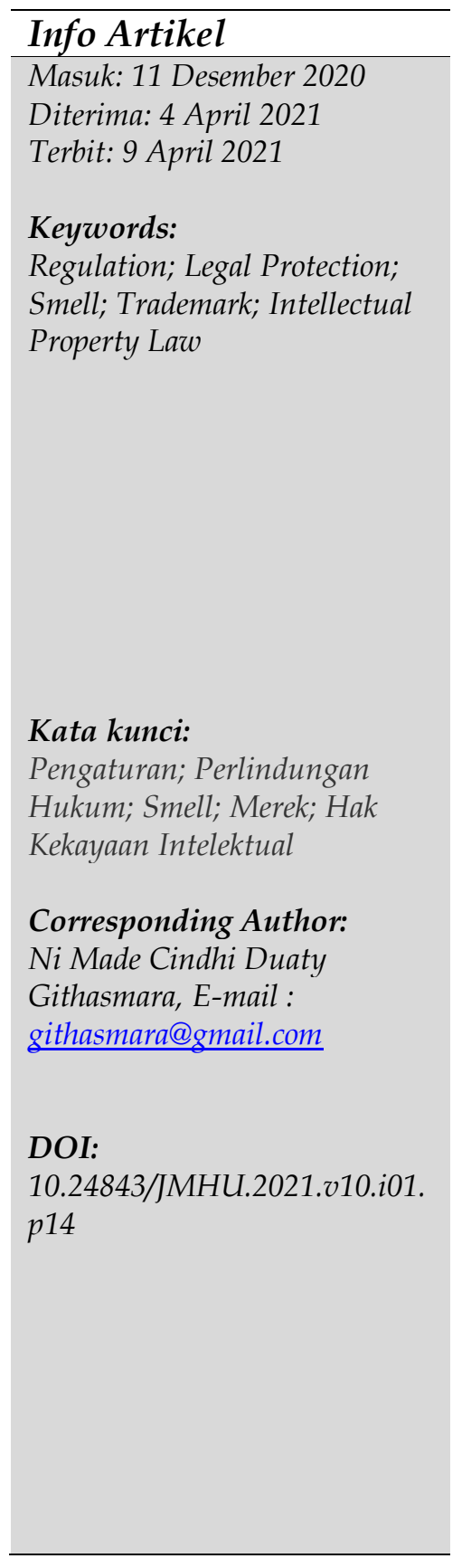

\begin{abstract}
The purpose of writing this journal is to find out how to regulate smell in trademark law in Indonesia and to find out how to regulate smell in trademark law in Indonesia in the future. The research method used in this journal is the normative legal research method, namely research by describing a problem which is then discussed using legal theories in accordance with statutory regulations. Research results show that trademark law in Indonesia in the future needs to regulate smell as a trademark because Indonesia is a member of the WTO-TRIPs which requires adjustments of national law to the agreement. In order to protect smell, Indonesia needs to pay attention to the policies of several countries in brand protection as stated in the brand definition. In addition, the need for regulation of smell is to help provide protection for inventors and speakers who have sacrificed their energy, time, and mind to produce the work, where the work is an original work.
\end{abstract}

Abstrak
Tujuan dari penulisan jurnal ini adalah untuk mengetahui
bagaimana pengaturan tentang smell dalam hukum merek di
Indonesia dan untuk mengetahui bagaiamana pengaturan
tentang smell dalam hukum merek di Indonesia pada masa
mendatang.Metode penelitian yang digunakan dalam jurnal ini
yaitu metode penelitian hukum normatif, yakni penelitian
dengan memaparkan suatu permasalahan yang selanjutnya
dibahas dengan menggunakan teori-teori hukum yang sesuai
dengan peraturan perundang-undangan.Hasil Penelitian
menunjukkan bahwa hukum merek di Indonesia pada masa
mendatang perlu mengatur smell sebagai merek karena Indonesia
tergabung dalam anggota WTO-TRIPs yang mengharuskan
penyesuaian hukum nasionalnya terhadap perjanjian tersebut.
Agar dapat melindungi smell, Indonesia perlu memperhatikan
kebijakan beberapa negara dalam perlindungan merek yang
tertuang dalam definisi merek. Selain itu perlunya pengaturan
terhadap smell adalah untuk membantu memberikan
perlindungan bagi penemu dan pencitpa yang telah
mengorbankan tenaga, waktu, serta pikirannya untuk
menghasilkan karya tersebut, dimana karya tersebut adalah karya
orisinil.




\section{Pendahuluan}

Perkembangan revolusi Industri telah menghasilkan perkembangan yang sangat pesat di bidang sains, teknologi dan budaya di mana perkembangan tersebut melahirkan jenis-jenis properti baru yang tidak berwujud (intangible) yang memerlukan perlindungan hukum. Kekayaan Intelektual lahir dari proses olah pikir manusia sebagai upaya untuk memenuhi kebutuhan hidup dalam masyarakat. Berbagai karyakarya intelektual yang baru dan unik sebagai proses olah pikir manusia diperlukan pengkajian yang lebih mendalam tentang konsep perlindungannya.

Pengertian merek diatur dalam Pasal 1 butir 1 UU No. 20 Tahun 2016 tentang Merek dan Indikasi Geografis yang menentukan bahwa: "Merek adalah tanda yang dapat ditampilkan secara grafis berupa gambar, logo, nama, kata, huruf, angka, susunan warna, dalam bentuk 2 (dua) dimensi dan/atau 3 (tiga) dimensi, suara, hologram, atau kombinasi dari 2 (dua) atau lebih unsur tersebut untuk membedakan barang dan/atau jasa yang diproduksi oleh orang atau badan hukum dalam kegiatan perdagangan barang dan/atau jasa. Hal ini sejalan dengan yang diatur dalam Article 15 TRIPs yang menetapkan merek adalah setiap tanda atau kombinasi dari tanda yang memiliki kemampuan untuk membedakan barang atau jasa dari suatu perusahaan dengan perusahaan lainnya harus dinyatakan sebagai merek.

Merek agar dapat diterima sebagai merek dagang atau merek jasa harus memenuhi syarat mutlak yakni merek tersebut harus memiliki daya pembeda yang cukup. ${ }^{1}$ Dengan kata lain, tanda atau sign harus mempunyai kekuatan untuk membedakan hasil produksi suatu perusahaan atau barang-barang perniagaan dengan hasil produksi perusahaan lain. ${ }^{2}$ Selain itu dikenal pula merek tradisional yang terdiri dari huruf, angka, kata, logo, gambar, simbol, atau kombinasi dari satu atau lebih dari unsur-unsur tersebut. Dalam perkembangannya beberapa negara maju telah memperkenalkan unsur-unsur baru di luar unsur-unsur merek yang telah diketahui selama ini seperti satu warna, tanda tiga dimensi berupa bentuk dan kemasan sebuah produksi, tanda-tanda yang dapat didengar, tanda-tanda yang dapat dicium, dan tanda-tanda bergerak. ${ }^{3}$

Toni P. Ashton dan David N. Katz menyatakan bahwa: “Merek dagang non-tradisional adalah merek dagang yang terdiri dari hal-hal seperti suara, aroma, rasa, sentuhan, hologram, dan tanda kinetik". ${ }^{4}$ Sejumlah negara juga membuka kemungkinan untuk pendaftaran bentuk-bentuk merek seperti warna tunggal tiga dimensi, tanda-tanda yang dapat didengar (bunyi) atau aroma (smell). Smell telah lama dipergunakan dalam bidang pemasaran suatu produk untuk memperkuat daya ingat suatu produksi bagi konsumen. Hal ini disebabkan karena smell dapat membangkitkan daya ingat manusia yang dikenal dengan olfactory.

\footnotetext{
${ }^{1}$ Nur Hidayati, "Perlindungan Hukum Pada Merek Yang Terdaftar," Ragam Jurnal Pengembangan Humaniora 11, no. 3 (2011).

${ }^{2}$ Fajar Nurcahya Dwi Putra, "Perlindungan Hukum Bagi Pemegang Hak Atas Merek Terhadap Perbuatan Pelanggaran Merek," Mimbar Keadilan, 2014, 240068.

3 Agung Sujatmiko, "Perjanjian Lisensi Merek Terkenal," Mimbar Hukum-Fakultas Hukum Universitas Gadjah Mada 22, no. 2 (2010): 252-64.

${ }^{4}$ Haedah Faradz, "Perlindungan Hak Atas Merek," Jurnal Dinamika Hukum 8, no. 1 (2008): 38-42.
} 
Pendaftaran smell sebagai merek telah lama menjadi perdebatan mengenai bagaimana pengakuan dan pengaturan perlindungannya. Walaupun beberapa negara telah mengakui dan mengatur tentang smell tetapi dalam hukum merek di Indonesia tidak mengatur smell sebagai suatu merek meskipun hal tersebut memiliki daya pembeda dan digunakan dalam perdagangan barang dan jasa, sehingga masih terjadi kekosongan hukum.

Berdasarkan atas uraian yang telah dipaparkan di atas, maka penting untuk menganalisis permasalahan yang terjadi dalam kekosongan hukum terkait pengaturan perlindungan hukum terhadap smell sebagai merek. Jurnal ilmiah ini ditulis dengan judul "Pengaturan Perlindungan Hukum Terhadap Smell Sebagai Merek Dalam Perspektif Hak Kekayaan Intelektual."

Adapun yang menjadi pokok permasalahan yang terdapat dalam latar belakang di atas adalah bagaimana pengaturan tentang smell dalam hukum merek di Indonesia serta bagaimana pengaturan smell sebagai merek di masa yang akan mendatang.

Tujuan dalam penulisan jurnal ilmiah ini ialah mengetahui pengaturan smell sebagai merek dalam hukum merek di Indonesia serta pengaturannya di masa yang akan mendatang.

\section{Metode Penelitian}

Metode yang digunakan dalam penulisan jurnal ilmiah ini adalah metode penelitian yuridis normatif, yaitu dengan mengkaji dan menganalisis pokok permasalahan dengan substansi Peraturan Perundang-Undangan lalu penelitian dengan memaparkan suatu permasalahan yang selanjutnya dibahas dengan menggunakan teori-teori hukum yang sesuai dengan peraturan perundang-undangan. ${ }^{5}$ Jenis pendekatan yang digunakan adalah pendekatan perundang-undangan yang mengacu pada peraturan, pendekatan konseptual yang berkaitan dengan prinsip-prinsip hukum dan pendekatan perbandingan dengan membandingkan sistem hukum suatu negara dengan sistem hukum negara lain. Pengumpulan bahan hukum yang digunakan ialah teknik kepustakaan. Analisis pada jurnal ini menggunakan teknik deskripsi pada bahan hukum primer dan sekunder yang telah dikumpulkan kemudian dikaitkan dengan teori serta literatur hukum sehingga dapat membantu dalam penulisan jurnal ini.

\section{Hasil dan Pembahasan}

\subsection{Pengaturan Tentang Smell Dalam Hukum Merek di Indonesia}

Dalam kehidupan sehari-hari, smell diterima dengan konteks yang kaya dan berarti, dan apa yang dicium adalah apa yang diharapkan berdasarkan informasi visual atau kontekstual. Pada umumnya, aroma atau smell digunakan untuk mendukung atau mengkonfirmasi identifikasi dari suatu objek. Smell memiliki peran yang sangat kuat yang dapat membangkitkan tanggapan emosional yang kuat. Smell yang tidak menyenangkan juga dapat mempengaruhi tanggapan emosional seseorang.

\footnotetext{
${ }^{5}$ Soerjono Soekanto, Penelitian Hukum Normatif Suatu Tinjauan Singkat (Jakarta: PT Grafindo Persada, 2015).
} 
Pada saat ini, hampir setiap produk yang beredar di pasar mengandung beberapa tipe smell. Salah satu kategori dari aroma adalah aroma primer yang mencakup produkproduk yang dibeli terutama karena daya tarik yang diterima oleh indera penciuman, seperti parfume, minyak esensial, dan pengharum ruangan. Aroma dari produk adalah aroma yang ditambahkan kepada produk tersebut, di mana produk tersebut memiliki fungsi lain yang lebih utama dibanding dengan fungsi aroma yang melekat. Smell dapat menjadi tanda yang efektif untuk membedakan merek yang diproduksi oleh suatu produsen dengan kompetitor dan smell dapat meningkatkan penjualan terhadap suatu merek. ${ }^{6}$

Merek memiliki nilai yang sangat besar bagi setiap produsen dari suatu produk. Peranan merek menjadi sangat penting di era global terutama dalam menjaga persaingan sehat. Dalam kerangka hukum Kekayaan Intelektual, merek termasuk bagian dari hak milik perindustrian. Konvensi Internasional yang mengatur perihal hak milik perindustrian adalah Konvensi Paris, Madrid Agreement, dan TRIPs Agreement. Sebagai negara anggota WTO-TRIPs Agreement, Indonesia telah melakukan harmonisasi substansi hukum merek sesuai dengan standar-standar internasional TRIPs Agreement ke dalam UU No. 20 Tahun 2016 tentang Merek dan Indikasi Geografis. $^{7}$

Pengertian merek diatur dalam Pasal 1 butir 1 UU No. 20 Tahun 2016 tentang Merek dan Indikasi Geografis yang menentukan bahwa: "Merek adalah tanda yang dapat ditampilkan secara grafis berupa gambar, logo, nama, kata, huruf, angka, susunan warna, dalam bentuk 2 (dua) dimensi dan/atau 3 (tiga) dimensi, suara, hologram, atau kombinasi dari 2 (dua) atau lebih unsur tersebut untuk membedakan barang dan/atau jasa yang diproduksi oleh orang atau badan hukum dalam kegiatan perdagangan barang dan/atau jasa. Hal ini sejalan dengan yang diatur dalam Article 15 TRIPs yang menetapkan merek adalah setiap tanda atau kombinasi dari tanda yang memiliki kemampuan untuk membedakan barang atau jasa dari suatu perusahaan dengan perusahaan lainnya harus dinyatakan sebagai merek.

Sebagai bagian dari Hak Atas Kekayaan Intelektual (HKI), merek (trademark) merupakan tanda (signs) yang berfungsi untuk mengidentifikasi asal barang dan jasa (an indication of origin). Dalam fungsi ini, merek berperan sebagai tanda pembeda antara barang yang satu dengan yang lain. Dalam perkembangannya kemudian, merek dibedakan menjadi merek tradisional dan merek non-tradisional. Kedua jenis tersebut terlihat pada perkembangan rumusan UU Merek, yaitu merek tradisional secara eksklusif pada UU Merek yang lama Undang-undang Nomor 15 Tahun 2001 tentang Merek dan keberadaan merek non-tradisional pada Undang-Undang Republik Indonesia Nomor 20 Tahun 2016 Tentang Merek Dan Indikasi Geografis.

Tanda yang tergolong tradisional adalah jenis tanda dengan ciri khas identitas visual (brand identity). Tanda ini memiliki sifat yang melekat dan dapat diidentifikasi secara kasat mata pada suatu barang dan jasa. Tanda non-tradisional adalah tanda yang

\footnotetext{
${ }^{6}$ Umar Haris Sanjaya, "Problematik Penerapan Undang-Undang Hak Kekayaan Intelektual Tentang Indikasi Geografik Pada Undang-Undang Merek," Jurnal Panorama Hukum 1, no. 2 (2016): 17-28.

${ }^{7}$ Ni Ketut Supasti Dharmawan, "Keberadaan Dan Implikasi Prinsip MFN Dan NT Dalam Pengaturan Hak Kekayaan Intelektual Di Indonesia," Jurnal Magister Hukum Udayana (Udayana Master Law Journal) 3, no. 2 (2014).
} 
sifatnya baru dalam hukum merek. Saat ini ada banyak tanda non-tradisional yang digunakan dalam aktivitas pasar tapi yang telah banyak dilindungi oleh berbagai Negara dan penting juga untuk dilindungi di Indonesia adalah sekurangnya tiga tanda yaitu bunyi, bentuk dan aroma. Tanda bentuk adalah berupa bentuk alat seperti botol/kemasan suatu produk. Pendaftarannya sebagai merek telah dilakukan oleh Coca Cola di Amerika Serikat pada 1916.

Bunyi adalah tanda berupa alunan nada yang menggambarkan barang atau jasa dalam pemasarannya. Pendaftaran bunyi telah dilakukan atas deru motor oleh Harley Davidson di Amerika pada 1997. Aroma, yaitu tanda yang memberikan bau dan harum yang berbeda sebagai pembeda antara produk. Prospek pendaftarannya terkenal dengan kasus smell of fresh cut grass di Belanda 1965. Ketiga jenis tanda tersebut saat ini eksis di Indonesia, tanda bunyi misalnya. Alunan nada dengan gambaran kata "paddle pop...paddle pop...super-duper yummy" merupakan tanda yang oleh konsumen sangat dikenal ketika membedakan pemasaran ice cream dari PT.Walls dengan ice cream dari pelaku usaha lain di Indonesia. Saat ini bunyi, bentuk dan aroma (BBA) belum dilindungi sebagai merek di Indonesia. Benar bahwa tanda bentuk dan bunyi telah disebutkan dalam UU Merek 2016 tentang Merek Dan Indikasi Geografis, tapi penyebutan tersebut bukanlah sebagai bentuk pemberian perlindungan. Penyebutan frasa tanda non-tradisional dalam UU Merek dan Indikasi Geografis adalah pemberian perlindungan yang sifatnya semu semata. Sebab secara prinsip perlindungan yang diberikan bersifat inapplicable yaitu mempersulit dan bahkan menutup kemungkinan perlindungan tanda non-tradisional tersebut sebagai merek.

Sistem perlindungan terhadap merek menganut sistem perlindungan Konstitutf atau yang dikenal dengan Fist to File System. Sistem perlindungan Konstitutif maksudnya bahwa hak atas merek diperoleh karena proses pendaftaran, yaitu pendaftar merek pertama yang mendapat ha katas merek. ${ }^{8}$ Mengenai perlindungan smell sebagai suatu merek harus memperhatikan konteks kekayaan intelektual karena pada hakikatnya merek dipakai oleh pemilik merek atau produsen untuk melindungi produk-produk yang dihasilkannya.

Pada negara-negara maju seperti Jepang, Inggris, dan Amerika Serikat telah memasukkan Kemasan dan Smell sebagai merek. Negara tersebut dapat menerima kemasan sebagai merek, begitu pula melalui Trademark Act 1994 Inggris dapat menerima smell sebagai merek. Dalam praktek yang ada di Eropa dan Amerika Serikat beberapa smell berhasil didaftarkan sebagai merek. Walaupun Indonesia tergabung sebagai anggota WTO-TRIPs Agreement tetapi ketentuan mengenai smell tidak diatur secara eksplisit dalam UU No. 20 Tahun 2016 tentang Merek dan Indikasi Geografis sehingga masih terjadi kekosongan hukum untuk mendapatkan perlindungan hukum atas smell.

Dalam menjawab rumusan masalah pertama digunakan Teori Kepastian Hukum yang menjadi acuan. Kepastian Hukum menurut Apeldoorn, mempunyai dua segi, pertama mengenai soal dapat dibentuknya (bepaalbaarheid) hukum dalam hal-hal yang konkret. Artinya pihak-pihak yang mencari Keadilan ingin mengetahui hukum dalam hal yang khusus sebelum memulai perkara. Kedua, kepastian hukum berarti keamanan hukum.

\footnotetext{
${ }^{8}$ Siti Marwiyah, "Perlindungan Hukum Atas Merek Terkenal," De Jure: Jurnal Hukum Dan Syar'iah 2, no. 1 (2010).
} 
Artinya perlindungan bagi para pihak terhadap kesewenangan Hakim. ${ }^{9}$ Dalam paradigma positivisme defenisi hukum harus melarang seluruh aturan yang mirip hukum, tetapi tidak bersifat perintah dari otoritas yang berdaulat, kepastian hukum harus selalu dijunjung tinggi apapun akibatnya dan tidak ada alasan untuk tidak menjunjung hal tersebut karena dalam paradigmanya hukum positif adalah satusatunya hukum. ${ }^{10}$ Teori ini dianggap relevan untuk menjawab rumusan permasalahan pertama karena sesuai dengan permasalahan pertama dimana smell sebagai merek di Indonesia belum jelas pengaturannya sehingga diperlukannya kepastian hukum terkait pengaturan smell tersebut.

Selain teori kepastian hukum, Utilitarian Teori dalam Teori Hak Kekayaan Intelektual juga dianggap relevan dalam menjadi acuan untuk rumusan permasalahan mengenai pengaturan smell ini. Utilitarian Teori diperkenalkan oleh Jeremy Bentham dan merupakan reaksi terhadap natural right theory. Menurut Bentham, natural righs merupakan "simple nonsense". Kritik ini muncul disebabkan oleh adanya fakta bahwa natural rights memberikan hak mutlak hanya kepada inventor dan tidak kepada masyarakat. Menurut Utilitarian theory, negara harus mengadopsi beberapa kebijakan misalnya peraturan perundang-undangan yang dapat memaksimalkan kebahagiaan anggota masyarakatnya. ${ }^{11}$ Pengaturan mengenai smell ini dapat berupa peraturan perundang-undangan yang dapat memberi perlindungan terhadap penggunaan smell ini sehingga dapat memberi kebahagiaan untuk masyarakat.

\subsection{Pengaturan Tentang Smell Sebagai Merek Dalam Hukum Merek di Indonesia Pada Masa Mendatang}

Amerika dan negara anggota Uni Eropa telah berkontribusi besar dalam perlindungan tanda non-tradisional sebagai merek dagang. Pandangan hukum merek pada masingmasing negara tersebut telah memprakarsai semangat bentuk, bunyi, dan aroma di berbagai negara di dunia. Amerika Serikat telah mengatur perlindungan bunyi, bentuk dan aroma sebagai suatu merek sejak tahun 1947. Bentuk perlindungan terhadap bunyi dilakukan berdasarkan Trademark Manual of Examining Procedure. Selain bunyi, Amerika Serikat juga telah memberikan perlindungan terhadap smell. Sama seperti bunyi, smell juga dilindungi dengan keistimewaan untuk tidak diharuskan adanya penggambaran tanda. ${ }^{12}$

In re Clarke merupakan kasus pertama dalam pendaftaran merek jenis tradisional ini. Pada tahun 1980 seorang perempuan bernama Celia Clarke menjalankan usaha yang melibatkan pengguna smell yaitu usaha benang berwangi. Smell tersebut dideskripsikan sebagai "a high impact, fresh, floral fragrance reminiscent of plumeria

\footnotetext{
${ }^{9}$ A Salman Maggalatung, "Hubungan Antara Fakta Norma, Moral, Dan Doktrin Hukum Dalam Pertimbangan Putusan Hakim," JURNAL CITA HUKUM 2, no. 2 (December 2014), https://doi.org/10.15408/jch.v1i2.1462.

${ }^{10}$ Inge Dwisvimiar, "KEADILAN DALAM PERSPEKTIF FILSAFAT ILMU HUKUM," Jurnal Dinamika Hukum 11, no. 3 (September 2011): 522-31, https://doi.org/10.20884/1.jdh.2011.11.3.179.

${ }^{11}$ Arief Budiono, "Teori Utilitarianisme Dan Perlindungan Hukum Lahan Pertanian Dari Alih Fungsi," Jurnal Jurisprudence 9, no. 1 (2019): 102-16.

${ }^{12}$ Rika Ratna Permata, M H SH, and Muthia Khairunnisa SH, "Perlindungan Hukum Merek Tidak Terdaftar Di Indonesia," Jurnal Opinio Juris 19, no. 1 (2016): 68-95.
} 
blossoms". Atas hal ini USPTO melakukan penolakan pendaftarannya sebagai merek dengan alasan aroma hanyalah merupakan efek samping dari produk dan tidak dapat mengindentifikasi sumber barang sebagai merek. Pandangan tersebut kemudian dibatalkan TTAB pada tingkat banding.

Smell sebagai merek harus dibedakan dengan aroma dalam barang dan jasa. Sebagai merek, aroma tidak mendukung dan/atau melengkapi fungsi utama dari barang atau jasa tersebut. Hal ini berbeda dengan aroma sebagai barang seperti pada "parfume" sehingga jelas merupakan karakter inti dari produk tersebut. Perlindungan terhadap smell kemudian didasarkan pada daya pembeda dan bukan fungsinya dalam barang atau jasa di perdagangan. Berbeda dengan smell sebagai merek produk yaitu pembeda produk. Dalam hal pertimbangan smell sebagai sifat yang fungsional maka dapat dilihat pada kasus pendaftaran smell kesegaran jeruk sebagai cat khusus lukisan. ${ }^{13}$

Berkaitan dengan hal di atas maka beberapa hal yang diisyaratkan terhadap smell adalah pembuktian terkait pembedaan tanda sebagai merek dalam mengidentifikasi sumber barang. Dalam kasus Clarke, pembuktian secondary meaning menjadi keharusan karena smell yang hendak didaftarkan gagal untuk terbukti. Pendaftaran smell di Amerika Serikat dilakukan dengan Musical Notes untuk tanda bunyi dan Onomatopoeia untuk tanda smell.

Pendaftaran bunyi, bentuk dan smell di Negara anggota Uni Eropa lebih mengedepankan penampilan secara grafis tanda. Jerman misalnya, pengaturan tentang bunyi, bentuk dan smell diatur dalam Pasal 8 ayat (2) The Gesetz uber den Schutz von Marken und sonstigen Kennzeichnungen. Penegasan penampilan grafis tersebut tidak bermakna literal terhadap jenis tanda. Artinya syarat perlindungan merek berdasarkan penampilan grafis adalah tidak berarti menolak tanda yang berjenis nonvisual. Dalam pendaftaran smell pada tingkat banding telah memberikan perlindungan terhadap merek aroma bola tenis yang dikenal dengan ungkapan "smell of fresh cut grass". ${ }^{14}$

Berbeda dengan Amerika Serikat, perlindungan di Negara anggota Uni Eropa lebih memperlakukan bunyi, bentuk, dan smell sebagai merek tradisional. Pendaftaran terhadap smell adalah pendaftaran secara grafis. Terhadap hal ini, pengadilan memutuskan bahwa setiap negara anggota dapat menentukan masing-masing bentuk penampilan tanda, berbeda dengan Amerika Serrikat yang focus pada deskripsi kata tentang tanda dan note musical.

Agar dapat melindungi smell, Indonesia perlu memperhatikan rumusan pengertian merek yang berbasis daya pembeda sebagai hukum positif. Penting untuk memperhatikan kebijakan beberapa negara dalam perlindungan merek yang tertuang dalam definisi merek. Faktor pembeda suatu tanda ditempatkan sebagai syarat utama dalam perlindungan suatu merek. Selain itu substansi pertama dalam rangka perlindungan smell di Indonesia adalah tentang penyebutan jenis tanda pada merek.

Rumusan yang perlu diperhatikan adalah penyebutan tanda secara eksplisit dan implisit. Selain secara implisit dan eksplisit penyebutan tanda dapat dilakukan secara

\footnotetext{
${ }^{13}$ Ranti Fauza Mayana, “Perlindungan Merek Non Tradisional Untuk Produk Ekonomi Kreatif Berdasarkan Undang-Undang Nomor 20 Tahun 2016 Tentang Merek, Indikasi Geografis Dan Perspektif Perbandingan Hukum," Jurnal Bina Mulia Hukum 2, no. 1 (2017): 26-41.

${ }^{14}$ Indra Rengkengbara Maasawet, "PERLINDUNGAN MEREK BERBASIS DAYA PEMBEDA DI INDONESIA," Jurnal Ilmu Hukum: ALETHEA 1, no. 1 (2017): 55-77.
} 
konteks seperti pada pengertian merek di Australia. Hal berikutnya yang perlu diperhatikan adalah semangat perlindungan smell di Indonesia mengenai penegasan sebab perlunya perlindungan, yaitu suatu tanda dapat diberikan perlindungan, sehingga hukum merek di Indonesia pada masa mendatang dipandang perlu untuk mengatur dan memberikan perlindungan terhadap smell sebagai merek.

Pengaturan dan perlindungan terhadap smell sebagai suatu merek merupakan bentuk tanggungjawab Indonesia sebagai negara anggota WTO-TRIPs yang mengharuskan Indonesia untuk menyesuaikan hukum nasionalnya dengan ketentuan dalam perjanjian tersebut. Jika Indonesia mengatur dan memberikan perlindungan terhadap smell sebagai merek, maka dapat dikatakan bahwa Indonesia telah ikut bekerjasama dengan negara-negara lain melalui harmonisasi smell sebagai suatu merek. Selain itu perlindungan hukum dalam kekayaan intelektual merupakan pemberian penghargaan atas materi yang telah dikeluarkan kepada setiap pencipta, yang merupakan suatu keadilan karena dia telah mengorbankan tenaga, waktu, serta pikirannya untuk menghasilkan karya tersebut, dimana karya tersebut adalah karya orisinil. ${ }^{15}$

Utilitarian Theory dalam Teori Hak Kekayaan Intelektual juga dianggap relevan dalam menjadi acuan untuk rumusan permasalahan mengenai pengaturan smell di masa mendatang ini. Utilitarian Theory diperkenalkan oleh Jeremy Bentham dan merupakan reaksi terhadap natural right theory. Menurut Bentham, natural righs merupakan "simple nonsense". Kritik ini muncul disebabkan oleh adanya fakta bahwa natural rights memberikan hak mutlak hanya kepada inventor dan tidak kepada masyarakat. Menurut Utilitarian theory, negara harus mengadopsi beberapa kebijakan misalnya peraturan perundang-undangan yang dapat memaksimalkan kebahagiaan anggota masyarakatnya. Pengaturan mengenai smell ini dapat berupa peraturan perundangundangan yang dapat memberi perlindungan baik di masa sekarang maupun masa mendatang terhadap penggunaan smell ini sehingga dapat memberi kebahagiaan untuk masyarakat.

Selanjutnya, Economic Growth Stimulus Theory dalam Teori Hak Kekayaan Intelektual juga dianggap relevan untuk menjawab permasalah kedua mengenai pengaturan smell dimasa mendatang. Teori ini mengakui bahwa perlindungan atas Hak Kekayaan Intelektual merupakan suatu alat dari pembangunan ekonomi, dan yang dimaksud dengan pembangunan ekonomi adalah keseluruhan tujuan dibangunnya suatu sistem perlindungan atas Hak Kekayaan Intelektual yang efektif. ${ }^{16}$ Pembangunan ekonomi disini merupakan sebuah pembangunan yang akan menimbulkan keuntungan di masa mendatang. Begitu juga mengenai pengaturan smell dimasa mendatang yang dianggap akan meningkatkan pembangunan terhadap perekonomian juga yang mana bermanfaat bagi pelaku usaha yaitu memberi perlindungan bagi smell milik pelaku usaha.

\footnotetext{
${ }^{15}$ Mohammad Amar Abdillah, "Perlindungan Hukum Pemilik Merek Tidak Terdaftar Atas Tindakan Pendaftaran Mereknya Oleh Pihak Lain Ditinjau Dari Asas Itikad Baik," JuristDiction 2, no. 4 (2019): 1357-74.

${ }^{16}$ Imas Rosidawati Wiradirja and Fontian Munzil, Pengetahuan Tradisional Dan Hak Kekayaan Intelektual: Perlindungan Pengetahuan Tradisional Berdasarkan Asas Keadilan Melalui Sui Generis Intellectual Property System (Refika Aditama, 2018). h. 43.
} 


\section{Kesimpulan}

Berdasarkan pembahasan yang telah dipaparkan diatas, diperoleh kesimpulan bahwa Pada saat ini, hampir setiap produk yang beredar di pasar mengandung beberapa tipe smell. Indonesia telah melakukan harmonisasi substansi hukum merek sesuai dengan standar-standar internasional TRIPs Agreement ke dalam UU No. 20 Tahun 2016 tentang Merek dan Indikasi Geografis. Walaupun Indonesia tergabung sebagai anggota WTO-TRIPs Agreement tetapi ketentuan mengenai smell tidak diatur secara eksplisit dalam UU No. 20 Tahun 2016 tentang Merek dan Indikasi Geografis sehingga masih terjadi kekosongan hukum untuk mendapatkan perlindungan hukum atas smell.

Amerika dan negara anggota Uni Eropa telah berkontribusi besar dalam perlindungan tanda non-tradisional sebagai merek dagang. Agar dapat melindungi smell, Indonesia perlu memperhatikan memperhatikan kebijakan beberapa negara dalam perlindungan merek yang tertuang dalam definisi merek. Faktor pembeda suatu tanda ditempatkan sebagai syarat utama dalam perlindungan suatu merek. Selain itu substansi pertama dalam rangka perlindungan smell di Indonesia adalah tentang penyebutan jenis tanda pada merek. Pengaturan dan perlindungan terhadap smell sebagai suatu merek merupakan bentuk tanggungjawab Indonesia sebagai negara anggota WTO-TRIPs. Perlindungan hukum dalam kekayaan intelektual merupakan pemberian penghargaan atas materi yang telah dikeluarkan kepada setiap pencipta, yang merupakan suatu keadilan karena dia telah mengorbankan tenaga, waktu, serta pikirannya untuk menghasilkan karya tersebut, dimana karya tersebut adalah karya orisinil.

\section{Daftar Pustaka}

Abdillah, Mohammad Amar. “Perlindungan Hukum Pemilik Merek Tidak Terdaftar Atas Tindakan Pendaftaran Mereknya Oleh Pihak Lain Ditinjau Dari Asas Itikad Baik." Jurist-Diction 2, no. 4 (2019): 1357-74.

Budiono, Arief. “Teori Utilitarianisme Dan Perlindungan Hukum Lahan Pertanian Dari Alih Fungsi." Jurnal Jurisprudence 9, no. 1 (2019): 102-16.

Dharmawan, Ni Ketut Supasti. "Keberadaan Dan Implikasi Prinsip MFN Dan NT Dalam Pengaturan Hak Kekayaan Intelektual Di Indonesia." Jurnal Magister Hukum Udayana (Udayana Master Law Journal) 3, no. 2 (2014).

Dwisvimiar, Inge. "KEADILAN DALAM PERSPEKTIF FILSAFAT ILMU HUKUM." Jurnal Dinamika Hukum 11, no. 3 (September 2011): 522-31. https://doi.org/10.20884/1.jdh.2011.11.3.179.

Faradz, Haedah. "Perlindungan Hak Atas Merek." Jurnal Dinamika Hukum 8, no. 1 (2008): 38-42.

Hidayati, Nur. "Perlindungan Hukum Pada Merek Yang Terdaftar." Ragam Jurnal Pengembangan Humaniora 11, no. 3 (2011).

Maasawet, Indra Rengkengbara. "PERLINDUNGAN MEREK BERBASIS DAYA PEMBEDA DI INDONESIA." Jurnal Ilmu Hukum: ALETHEA 1, no. 1 (2017): 5577.

Maggalatung, A Salman. "Hubungan Antara Fakta Norma, Moral, Dan Doktrin Hukum Dalam Pertimbangan Putusan Hakim." JURNAL CITA HUKUM 2, no. 2 (December 2014). https://doi.org/10.15408/jch.v1i2.1462.

Marwiyah, Siti. "Perlindungan Hukum Atas Merek Terkenal." De Jure: Jurnal Hukum Dan Syar'iah 2, no. 1 (2010). 
Mayana, Ranti Fauza. "Perlindungan Merek Non Tradisional Untuk Produk Ekonomi Kreatif Berdasarkan Undang-Undang Nomor 20 Tahun 2016 Tentang Merek, Indikasi Geografis Dan Perspektif Perbandingan Hukum." Jurnal Bina Mulia Hukum 2, no. 1 (2017): 26-41.

Permata, Rika Ratna, M H SH, and Muthia Khairunnisa SH. "Perlindungan Hukum Merek Tidak Terdaftar Di Indonesia." Jurnal Opinio Juris 19, no. 1 (2016): 68-95.

Putra, Fajar Nurcahya Dwi. "Perlindungan Hukum Bagi Pemegang Hak Atas Merek Terhadap Perbuatan Pelanggaran Merek." Mimbar Keadilan, 2014, 240068.

Sanjaya, Umar Haris. "Problematik Penerapan Undang-Undang Hak Kekayaan Intelektual Tentang Indikasi Geografik Pada Undang-Undang Merek." Jurnal Panorama Hukum 1, no. 2 (2016): 17-28.

Soekanto, Soerjono. Penelitian Hukum Normatif Suatu Tinjauan Singkat. Jakarta: PT Grafindo Persada, 2015.

Sujatmiko, Agung. "Perjanjian Lisensi Merek Terkenal." Mimbar Hukum-Fakultas Hukum Universitas Gadjah Mada 22, no. 2 (2010): 252-64.

Wiradirja, Imas Rosidawati, and Fontian Munzil. Pengetahuan Tradisional Dan Hak Kekayaan Intelektual: Perlindungan Pengetahuan Tradisional Berdasarkan Asas Keadilan Melalui Sui Generis Intellectual Property System. Refika Aditama, 2018. 